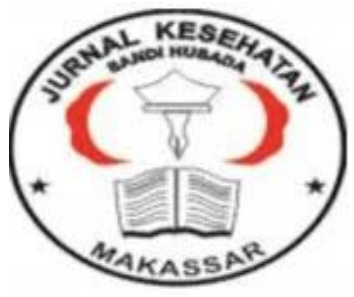

\author{
Jurnal Ilmiah Kesehatan Sandi Husada \\ hhttps://akper-sandikarsa.e-journal.id/JIKSH \\ Volume 9, Nomor 2, Desember 2020, pp 591-596 \\ p-ISSN: 2354-6093 dan e-ISSN: 2654-4563 \\ DOI: $10.35816 /$ jiskh.v10i2.357
}

\title{
Pengaruh Pemberian Asiklovir dalam Menurunkan Progresifitas dan Transmisi HIV
}

Effects of Acyclovir Administration in Decreasing HIV Progression and Transmission

M Rafli Febri Asshiddiq
Universitas Lampung

Artikel history:

Received; Juni 2020

Revised: Juli 2020

Accepted;Juli 2020
Abstrak. Latar belakang: Epidemi HIV/AIDS memberikan tantangan berat bagi pembangunan dan kemajuan sosial. HIV merupakan virus yang ditularkan terutama melalui hubungan seksual, jalur intravena yang digunakan secara bersamaan, dan transmisi ibu ke anak yang dapat terjadi saat proses kelahiran ataupun menyusui. HIV terutama disebabkan karena infeksi HIV-1 atau HIV-2, retrovirus yang tergolong dalam famili retroviridae, genus Lentivirus. Pengobatan dengan terapi anti-retroviral memberikan hasil efektif dan telah membantu menjaga kesehatan bagi mereka dengan infeksi HIV namun angka mortalitas terkait HIV tetap tinggi. Upaya pencegahan dilakukan untuk menurunkan angka mortalitas maupun morbiditas terkait HIV. Salah satu upaya pencegahan yang dapat dilakukan adalah pemberian asiklovir namun hal ini masih kontroversial. Asiklovir adalah agen yang digunakan untuk mengobati infeksi yang disebabkan oleh virus herpes simpleks (HSV). Tujuan: Mengetahui peran dari asiklovir dalam menurunkan transmisi penularan HIV. Metode: Menggunakan studi letarute dari junal baik nasional maupun internasional dengan meringkas topik pembahasan dan membandingkan hasil yang disajikan dalam artikel. Hasil: Koinfeksi HIV dengan HSV dapat meningkatkan laju transmisi dan progresifitas penyakit. Pengobatan utama untuk herpes simpleks adalah dengan asiklovir. Asiklovir dengan dosis $2 \times 400 \mathrm{mg}$ dan valasiklovir dengan dosis $2 \times 500 \mathrm{mg}$ berperan dalam mengurangi progresifitas penyakit. Asiklovir mempunyai efek anti-HIV secara langsung. Namun asiklovir tidak menurunkan laju transmisi dari HIV itu sendiri. Kesimpulan: Asiklovir berperan dalam menurunkan angka kematian dan progresifitas HIV menjadi AIDS dengan adanya efek anti-HIV secara langsung.

Abstract. Background: The HIV / AIDS epidemic presents severe challenges for development and social progress. HIV is 
a virus that is transmitted mainly through sexual contact, intravenous lines that are used together, and mother to child transmission that can occur during the process of birth or breastfeeding. HIV is mainly caused by infection with HIV-1 or $H I V-2$, a retrovirus of the family retroviridae, genus Lentivirus. Treatment with anti-retroviral therapy has been effective and has helped to maintain health for those with HIV infection but HIV-related mortality rates remain high. Prevention efforts are made to reduce mortality and morbidity related to HIV. One of the prevention efforts that can be done is using acyclovir but this is still controversial. Acyclovir is an agent used to treat infections caused by the herpes simplex virus (HSV). Objective: To determine the role of acyclovir in reducing transmission of HIV transmission. Method: Using literature studies from both nationally and internationally journal by summarizing the topic of discussion and comparing the results presented in the article. Results : HIV coinfection with HSV can increase transmission and disease progression. The main treatment for herpes simplex is with acyclovir. Acyclovir at a dose of $2 \times 400 \mathrm{mg}$ and valacyclovir at a dose of $2 \times 500 \mathrm{mg}$ reduce the progression of the disease. Acyclovir has a direct anti-HIV effect. But acyclovir does not reduce transmission from HIV itself. Conclusion: Acyclovir plays a role in reducing mortality and the progression of HIV to AIDS with direct anti-HIV effects

Keywords:
HIV;
Asiklovir;
HSV;

Coresponden author:
Email: asshiddiqfebri27@gmail.com

artikel dengan akses terbuka dibawah lisensi CC BY-NC-SA -4.0

\section{Pendahuluan}

Human immunodeficiency virus (HIV) adalah virus yang berisi 2 salinan genom RNA beruntai tunggal. HIV dapat menyebabkan acquired immunodeficiency syndrome (AIDS) yang merupakan tahap terakhir dari penyakit HIV. Sekitar 4 hingga 10 minggu setelah HIV memasuki tubuh, pasien akan mengeluhkan gejala infeksi primer (Brew, 2018). Perkiraan jumlah orang yang hidup dengan HIV / AIDS adalah 36,7 juta di seluruh dunia pada tahun 2016. Di Amerika Serikat, faktor risiko penting untuk penyebaran HIV di kalangan anak muda selain hubungan seksual adalah penggunaan obat-obatan termasuk ganja, kokain, dan Ekstasi. Faktor risiko lain yang terkait dengan risiko tertular infeksi HIV termasuk pria yang berhubungan seks dengan pria, penggunaan obat intravena, dan transfusi darah atau produk darah yang tidak aman (Javadi, Menias, Karbasian \& Shaaban, 2018). HIV adalah virus berbentuk spherical yang menempel pada sel inang dengan bantuan glikoprotein. HIV menginvasi dengan cara mengintegrasikan bahan kromosom ke dalam sel inang, mengambil alih sel untuk menghasilkan lebih banyak protein virus. Sel inang pada akhirnya akan mati, dan sel CD4 lainnya akan terinfeksi. Jumlah sel CD4 dalam individu yang terkena HIV akan turun sekitar 50-80 sel / tahun tanpa ART, dan penurunan akan terjadi lebih cepat setelah jumlah CD4 turun di bawah 200 sel / uL (Chen, 2016). Infeksi primer terjadi 4 hingga 10 minggu setelah melakukan hubungan seksual berisiko dengan orang yang terinfeksi HIV. Infeksi HIV primer ditandai dengan gejala seperti 
demam, nyeri sendi, ruam kulit, sakit tenggorokan dan pembengkakan kelenjar getah bening [Brew, 2018). Sedangkan infeksi HIV kronis ditandai dengan tanda dan gejala seperti demam, kelelahan, diare, penurunan berat badan, herpes zoster, limfadenopati generalisata, dan sariawat. Gejala dapat bertahan selama beberapa dekade (Capriotti, 2018). Menggunakan obat-obatan HIV untuk pengobatan disebut terapi antiretroviral (ART). Bentuk terapi ini direkomendasikan untuk semua pasien dengan HIV oleh Departemen Kesehatan dan Layanan Kemanusiaan (DHHS) dan Organisasi Kesehatan Dunia (WHO) (Kemnic, Gulick, 2020).

Diperlukan edukasi mengenai tingkat jumlah CD4 serta peran ART dalam mempertahankan fungsi kekebalan tubuh. Pasien harus diberitahu tentang infeksi oportunistik, keganasan, dan kondisi komorbiditas yang mungkin terjadi dengan infeksi HIV (Feinberg, 2017). Pencegahan utama berdasarkan obat antiretroviral telah menekankan pentingnya kepatuhan pasien untuk konsumsi obat secara rutin. Pencegahan lainnya yang dapat dilakukan adalah dengan tidak melakukan hubungan seksual berisiko, menghindari penggunaan jarum intravena secara bersamaan, dan transfusi darah yang tidak aman (Padian, 2011). Baru baru ini terdapat penelitian yang meneliti penggunaan asiklovir terhadap penurunan transmisi HIV. Penggunaan asiklovir harian dapat menurunkan HIV viral load dan dapat mengurangi efek samping yang ditimbulkan dari penggunaan ARV. (Van Wagoner, 2014). Terdapat beberapa penelitian yang menjelaskan bahwa pengobatan herpes simpleks virus selama 8 - 12 minggu dapat menurunkan kadar viral load dari HIV itu sendiri. Pada literature review kali ini akan dibahas mengenai penggunaan asiklovir untuk menurunkan kadar viral load pada pasien HIV sehingga mengurangi laju transmisi dan progresifitas penyakit (Celum, 2010).

\section{Metode}

Metode penelitian ini menggunakan studi literature dari berbagai jurnal internasional. Metode ini digunakan dengan tujuan menambah ilmu pengetahuan terkait topik yang dibahas dengan meringkas topik pembahasan. Metode ini memberikan informasi fakta atau analisa terkait tinjaut literature yang relevan kemudian membandingkan hasil tersebut dalam sebuah artikel

\section{Hasil Dan Pembahasan}

Asiklovir adalah agen yang digunakan untuk mengobati infeksi yang disebabkan oleh virus herpes simpleks (HSV). Asiklovir disetujui FDA untuk mengobati herpes genital dan ensefalitis HSV. Indikasi penggunaan asiklovir yang tidak disetujui FDA adalah untuk menangani HSV mukokutan, herpes zoster dan varicella-zoster (cacar air) (Ahronowitz, 2018) (Gori, Caldarola, De Simone, 2019). Asiklovir adalah pengobatan lini pertama untuk ensefalitis HSV. Saat ini, tidak ada obat lain yang diindikasikan untuk perawatan kondisi ini (Stahl, 2019). Pada pasien dengan human immunodeficiency virus (HIV), acyclovir digunakan untuk mengobati eksim herpeticum. Asiklovir juga digunakan untuk mencegah infeksi pada kulit, mata, hidung, dan mulut. Eksim herpeticum jarang terjadi tetapi cepat berkembang jika tidak diobati. Pasien HIV dengan keterlibatan organ sistemik, gejala sistemik, atau penurunan asupan oral harus menjalani rawat inap untuk pengobatan asiklovir secara intravena (Ozcan, Kahale, Nguyen, 2019). Selain itu, asiklovir dapat digunakan untuk leukoplakia (Hadzavdic, 2018). Asiklovir adalah agen antivirus yang bekerja di dalam DNA virus. Obat ini menghambat sintesis DNA dan replikasi virus setelah dikonversi menjadi asiklovir trifosfat oleh enzim seluler. Acyclovir adalah analog nukleosida purin sintetis yang menunjukkan aktivitas penghambatan in vitro dan in vivo terhadap kedua virus herpes simplex tipe 1 (HSV-1), 2 (HSV-2), dan virus varicella-zoster 
(Kukhanova, Korovina, kochetkov, 2014).

Seroprevalensi virus herpes simpleks tipe 2 (HSV-2), penyebab paling umum dari ulkus genital di seluruh dunia, adalah 60 hingga $90 \%$ pada populasi dengan virus human immunodeficiency virus tipe 1 (HIV-1). Manifestasi klinis HSV-2 mulai dari gejala genital yang ringan pada kebanyakan orang hingga penyakit ulkus genital yang parah pada orang dengan penyakit HIV (Celum, 2010). HIV dan HSV-2 adalah infeksi menular seksual (IMS) yang dikaitkan dengan faktor risiko yang serupa (usia, jenis kelamin, jumlah pasangan seksual, penggunaan kondom, dan lainnya). Selain itu, terdapat bukti interaksi langsung antara HIV dan HSV-2. Infeksi HSV-2 aktif melibatkan konsentrasi tinggi sel T CD4-positif, yang merupakan sel target untuk HIV. Pada pasien dengan HSV apabila terdapat ulkus di daerah genital dapat menyebabkan kerusakan di lapisan mukosa di mana HIV dapat masuk. Koinfeksi dengan HIV meningkatkan transmisi genital HSV-2, sementara infeksi HSV-2 berkorelasi dengan peningkatan viraemia dan penularan HIV (Looker, 2017). Sejumlah penelitian observasional menjelaskan bahwa peningkatan risiko penularan HIV 2-3 kali lipat lebih tinggi apabila pasien juga memiliki infeksi HSV-2. Sebaliknya, infeksi HIV meningkatkan risiko terkena infeksi HSV-2 sekitar 3-5 kali lipat lebih tinggi (Barnabas, 2012).

Pemberian acyclovir 400mg dua kali sehari pada pasien dengan HSV-2 koinfeksi HIV mengurangi risiko pengembangan penyakit HIV sebesar 25\%. Mekanisme aksi asiklovir pada progresifitas penyakit HIV tetap menjadi bahan perdebatan. Asiklovir adalah agen dengan target yang sangat spesifik dari virus herpes simpleks. (Reynolds, 2012). Sebuah penelitian dari Kenya menggunakan dosis tinggi (valacyclovir 1,5g dua kali sehari) melaporkan penurunan yang signifikan dalam viral load HIV (Mugwanya, 2011). Penelitian meta-analisa menjelaskan bahwa terapi supresif virus herpes simpleks dosis standar (asiklovir $400 \mathrm{mg}$ atau valasiklovir $500 \mathrm{mg}$ dua kali sehari) di antara orang koinfeksi HIV dan HSV-2 mengurangi tingkat viral load HIV plasma sebesar 0,25-0,53 $\log 10$ per mililiter dan asiklovir memperlambat progresifitas HIV pada pasien yang tidak menerima pengobatan ART. Mekanisme yang bekerja dimana terapi anti-HSV menurunkan tingkat RNA HIV plasma mencakup penurunan sitokin proinflamasi, penurunan aktivasi transkripsi HIV-1 oleh protein yang dikodekan HSV, dan penghambatan langsung HIV-1 reverse transcriptase. Dalam penelitian yang sama, valacyclovir dengan dosis $1000 \mathrm{mg}$ dua kali sehari, mengurangi tingkat viral load HIV-1 plasma sebesar 0,27 $\log 10$ per mililiter lebih dari asiklovir dosis standar (400mg dua kali sehari) pada pasien seropositif HIV dan HSV yang tidak menjalani pengobatan ART. Namun tidak menunjukkan perbedaan berarti apabila dibandingkan penggunaan valacyclovir $100 \mathrm{mg}$ dua kali sehari dengan penggunaan valacyclovir $500 \mathrm{mg}$ dua kali sehari. (Perti, 2013). Penelitian lainnya yang mendukung dilakukan oleh Vanpouille et al pada pasien HIV tanpa infeksi HSV-2 menjelaskan bahwa Valasiklovir mengurangi viral load HIV dalam plasma sebesar 0,37 $\log 10$. Konsentrasi viral load HIV kembali ke tingkat awal setelah penghentian pengobatan valasiklovir, sesuai dengan waktu paruh obat. Penurunan VL HIV yang dimediasi oleh valasiklovir memiliki efek yang menguntungkan. Hal ini disebabkan karena pengembangan menjadi penyakit AIDS atau kematian berkurang 25\% dengan setiap penurunan 0,3 $\log 10$ dalam VL HIV. Penurunan viral load HIV memberikan bukti bahwa efek asiklovir pada HIV tidak terbatas pada kehadiran HSV-2 dan menunjukkan bahwa asiklovir memiliki aktivitas anti-HIV-1 secara langsung (Vanpouille, 2015).

Menurut teori penularan HIV terkait erat dengan viral load dari HIV dan penggunaan ART untuk mengurangi viral load adalah metode pengendalian HIV yang sangat efektif untuk mencegah penularan HIV baik secara vertikal ataupun hubungan seksual. Dampak valasiklovir pada viral load HIV diharapkan menurunkan transmisi HIV itu sendiri. 
Penurunan viral load sebesar $1 \log 10$ menyiratkan penurunan 59\% dalam transmisi infeksi HIV (Tanton, 2011). Penelitian yang dilakukan oleh Celum et al terhadap pasien HIV-1 menunjukkan bahwa di antara pasangan yang terinfeksi HIV dan HSV-2 dan yang memiliki jumlah CD4 $>250$ per milimeter kubik, pengobatan dengan dosis standar asiklovir untuk infeksi HSV-2 tidak mengurangi kejadian penularan HIV ke pasangan yang tidak terinfeksi. Meskipun didapatkan penurunan yang signifikan dalam kadar viral load HIV dalam plasma dan dalam kejadian penyakit ulkus kelamin (Celum, 2010).

\section{Simpulan Dan Saran}

Salah satu tindakan pencegahan yang dapat dilakukan untuk menurunkan progresifitas penyakit HIV adalah dengan pemberian asiklovir. Asiklovir atau valasiklovir merupakan pengobatan utama untuk herpes simpleks. Asiklovir dipercaya mempunyai beberapa efek menguntungkan terkait penggunaannya untuk pasien HIV. Asiklovir tidak hanya menyembuhkan penyakit herpes simpleks dimana seperti yang sudah diketahui bahwa koinfeksi HIV dengan HSV dapat meningkatkan laju transmisi serta progresifitas penyakit. Asiklovir mempunyai mekanisme sendiri terhadap progresifitas penyakit HIV. Pengobatan dengan asiklovir $2 \times 400 \mathrm{mg}$ atau valasiklovir 2 x $500 \mathrm{mg}$ memiliki efek dalam menurunkan kadar viral load HIV dalam plasma. Durasi waktu yang digunakan berbeda beda setiap penelitian berkisar dari 8 - 12 minggu. Penurunan kadar viral load HIV berdampak pada berkurangnya progresifitas menjadi AIDS dan juga kematian. Penurunan kadar viral load HIV dapat berdampak pada menurunnya transmisi. Namun dari seluruh penelitian yang telah ditinjau didapatkan bahwa pemberian asiklovir atau valasiklovir dapat menurunkan progresifitas penyakit HIV tetapi tidak pada transmisi. Penelitian yang lebih lanjut dengan waktu yang lebih lama dan kualitas yang lebih baik diperlukan untuk menentukan penggunaan asiklovir dalam mencegah progresifitas dan transmisi dari HIV.

\section{Daftar Rujukan}

Ahronowitz, I., Fox, L, P,. (2018). Herpes zoster in hospitalized adults: Practice gaps, new evidence, and remaining questions. J. Am. Acad. Dermatol ;78(1):223-230.e3.

Barnabas, R. V. (2012). Impact of Herpes Simplex Virus Type 2 on HIV-1 acquisition and progression in an HIV vaccine trial (the Step Study). J Acquir Immune Defic Syndr

Brew, B. J,. Garber, J. Y. (2018). Neurologic sequelae of primary HIV infection. Handb Clin Neurol.152:65-74.

Capriotti, T. (2018). HIV/AIDS: An Update for Home Healthcare Clinicians. Home Healthc Now

Celum, C. (2010). Acyclovir and Transmission of HIV-1 from Persons Infected with HIV-1 and HSV-2. N Engl J Med.

Chen, B. (2016). HIV Capsid Assembly, Mechanism, and Structure. Biochemistry

Feinberg, J,. Keeshin, S,. (2017). Management of Newly Diagnosed HIV Infection. Ann. Intern. Med

Gori, N,. Caldarola, G,. De Simone, C,. (2019). Annular elastolytic giant cell granuloma following herpes zoster infection. J Eur Acad Dermatol Venereol. 33(9):e334e335

Javadi, S,. Menias, C, O,. Karbasian, N,. Shaaban, A,. (2018). HIV-related Malignancies and Mimics: Imaging Findings and Management. Radiographics.

Kukhanova, M, K,. Korovina, A, N,. Kochetkov, S, N,. (2014). Human herpes simplex virus: life cycle and development of inhibitors. Biochemistry Mosc.

Ljubojevic, H, S.. (2018). Genital Herpes Zoster as Possible Indicator of HIV Infection. Acta Dermatovenerol Croat. 
Looker, K, J.. (2017). Effect of HSV-2 infection on subsequent HIV acquisition: an updated systematic review and meta-analysis. Lancet Infect Dis

Mugwanya, K,. (2011). High-dose Valacyclovir HSV-2 Suppression Results in Greater Reduction in Plasma HIV-1 Levels Compared With Standard Dose Acyclovir Among HIV-1/HSV-2 Coinfected Persons: A Randomized, Crossover Trial

Ozcan, A,. Kahale ,K,. Nguyen, D,. (2019). An 8-Month-Old Girl With Vesicular Rash. Glob Pediatr Health.

Padian, N, S,. McCoy, S, I,. (2011). HIV prevention transformed: the new prevention research agenda

Perti, T,. (2013). High-Dose Valacyclovir Decreases Plasma HIV-1 RNA More Than Standard-Dose Acyclovir in Persons Coinfected with HIV-1 and HSV-2: A Randomized Crossover Trial. J Acquir Immune Defic Syndr.

Reynold. (2013). Daily acyclovir to prevent disease progression among HIV-1/HSV-2 coinfected individuals: a randomized, double-blinded placebo controlled trial in Rakai, Uganda. Lancet Infect Dis

Stahl, J, P,. Mailles, A,. (2019). Herpes simplex virus encephalitis update. Curr. Opin. Infect. Dis

Tanton, C,. (2011). Time to Refocus on HSV Interventions for HIV Prevention? Editorial Commentary.

Tyler, R,. Peter, G, G,. (2020). HIV Antiretroviral Therapy. StatPearls

Van Wagoner, N,. (2014). The effect of valacyclovir on HIVand HSV-2 in HIV-infected personson antiretroviral therapy with previouslyunrecognised HSV-2. International Journal of STD \& AIDS.

Vanpouille, C,. (2015). Valacyclovir Decreases Plasma HIV-1 RNA in HSV-2 Seronegative Individuals: A Randomized Placebo-Controlled Crossover Trial. Clinical Infectious Diseases 